\title{
Liquid Effluent Retention Facility Basin 42 Studies
}

\author{
J. B. Duncan \\ CH2M AILL Hanford Group, Ine. \\ Richland, WA 99352 \\ U.S. Department of Energy Contract DE-AC27-99RL14047

\section{EDT/ECN:} \\ Cost Center: $75: 10$ \\ B\&R Code: \\ UC: \\ Charge Code: 502074 \\ Total Pages: 23 \\ Key Words: process, condensate, liquid, effluert, reterition, facility
}

\begin{abstract}
:
This report documents laboratory resulls obtained under test plan R.PP-21533 for samples submitted by the Effluent Treatment Facility from the Liquid Effluent Retention Facility Basin 42 .
\end{abstract}

TRADEMARK DISCLAIMER. Reference herein to any speclifc commerclal product, process, or service by trade name, trademark, manufacturer, or atherwise, does not necessarily constitute or imply its endorsement, recommendation, or favoring by the United States Government or any agency thereof or its contractors or subcontractors.

Printed in the United States of America. To obtah coples of this document. contact: Document Control Services, P.O. Box 950. Mailstop H6-08, Richland WA 99352, Phone (509) 372-2420; Fax (509) 376-4989.
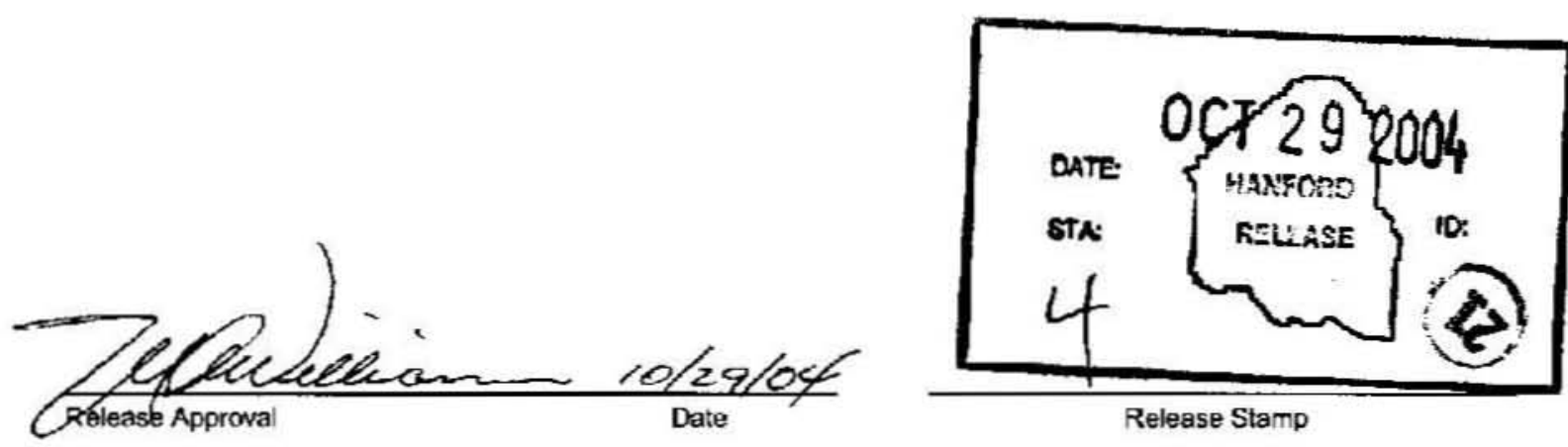

Approved For Public Release 
RPP-RPT-22879

Revision 0

\title{
Liquid Effluent Retention Facility Basin 42 Studies
}

\author{
J. B. Duncan \\ CH2M HILL Hanford Group, Inc.
}

Date Published

October 2004

Hanford Group, inc.

Prepared for the U.S. Department of Energy

Office of River Protection

Contract No. DE-AC27-99RL14047 


\section{Table of Contents}

1. INTRODUCTION

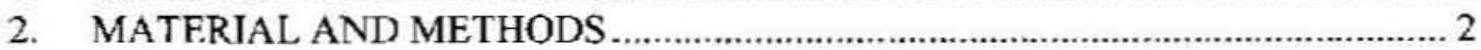

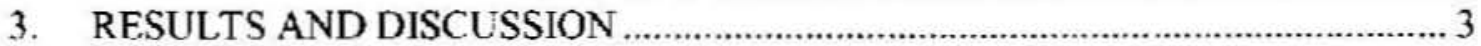

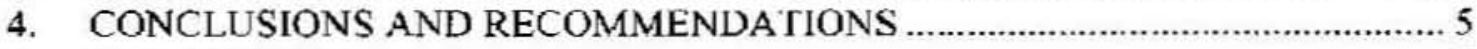

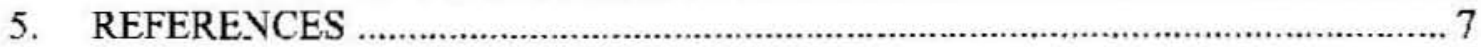

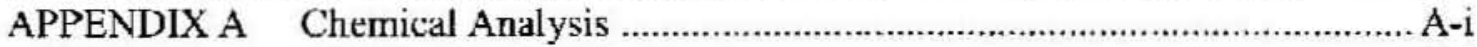

APPENDIX B CUNO PolyNet Specitications ...................................................... B-i

\section{Figures}

Figure 1. Slime Buildup Inside the Filter Housing During Basin 42 Campaign............. 1

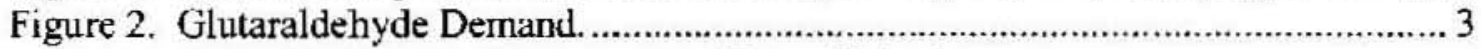

Figure 3. Basin 42 Microbial Response to Glutaraldehyde........................................ 4

Figure 4. SEM of Basin 42 Filter Retentate on 0.45-Micron Filter................................. 5

Figure 5. Suggested Test Configuration for PolyNet and ProSep Filters.......................... 6 


\section{INTRODUCTION}

This report documents laboratory results obtained under test plan RPP-21533 for samples submitted by the Effluent Treatment Facility (ETF) from the Liquid Effluent Retention Facility (LERF) Basin 42 (Reference 1).

The LERF Basin 42 contains process condensate (PC) from the 242-A Evaporator and landfill leachate. The ETF processes one PC campaign approximately every 12 to 18 months. A typical $\mathrm{PC}$ campaign volume can range from 1.5 to 2.5 million gallons. During the September 2003 ETF Basin 42 processing campaign, a recurring problem with "gelatinous buildup" on the outlet filters from 60A-TK-1 (surge tank) was observed (Figure 1). This buildup appeared on the filters after the contents of the surge tank were adjusted to a $\mathrm{pH}$ of between 5 and 6 using sulfuric acid. Biological activity in the PC feed was suspected to be the cause of the gelatinous material. Due to this buildup, the filters $\left(10 \mu \mathrm{m} \mathrm{CUNO}^{1}\right)$ required daily change out to maintain process throughput.

Figure 1. Slime Buildup Inside the Filter Housing During Basin 42 Campaign.

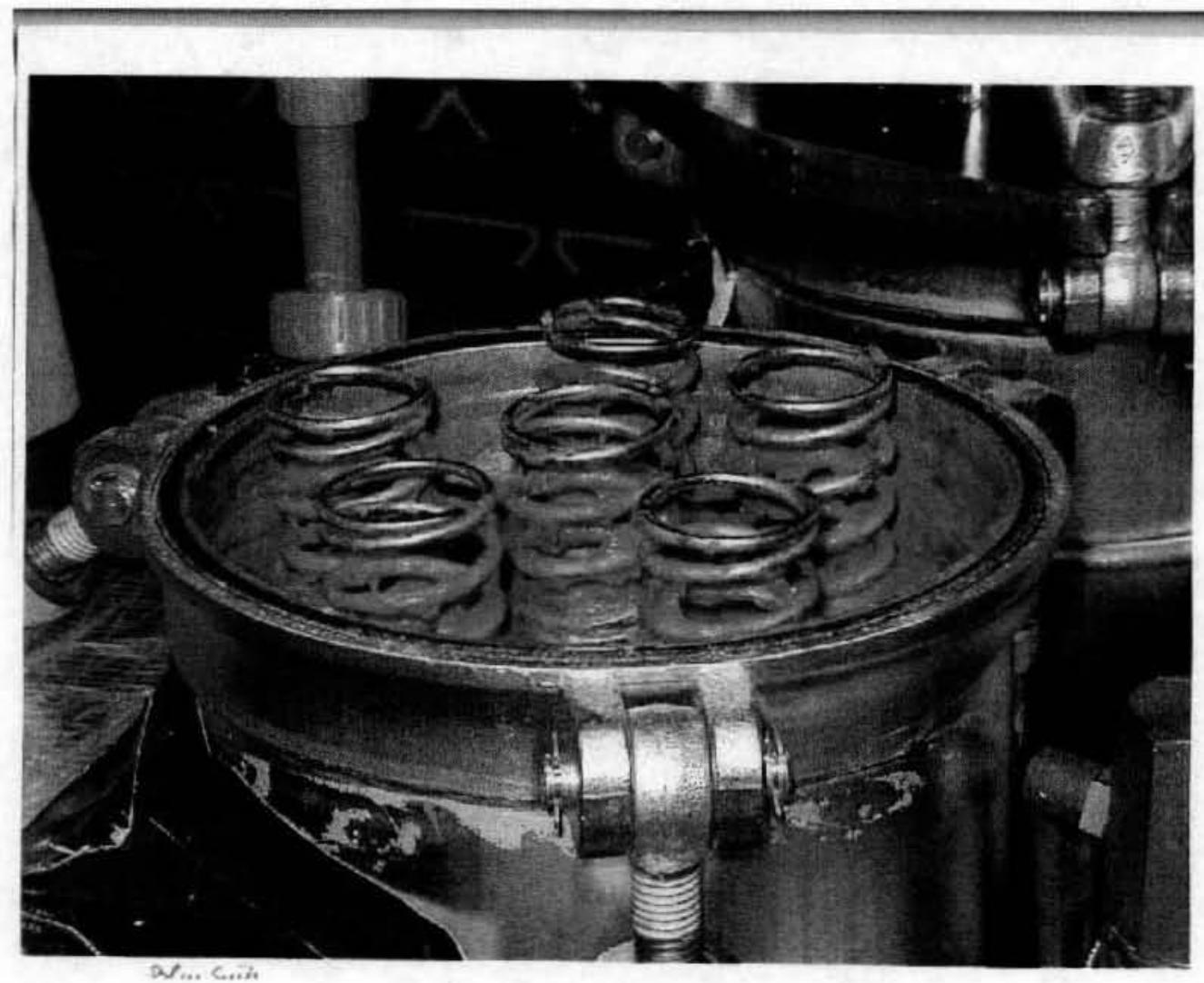

\footnotetext{
${ }^{1}$ CUNO is a registered trademark of CUNO Incorporated, Meriden, Connecticut.
} 
ETF personnel obtained the sample material received at the 222-S Laboratory, which was taken from Riser 2 of Basin 42 at the 3-loot level. The samples arrived in three 3-gallon carboys (approximately 9 gallons). The material was clear and had a definite odor of an ammonia/amine mixture. Aliquots from each carboy were submitted for $\mathrm{pH}$ and analyses using ion chromatngraphy and inductively coupled plasma spectrometry. The results are presented in Appendix A.

The ficld observations could not be reproduced in the laboratory. Therefore, it was not possible to collect data concerning filtration of gelatinous material. However, microbial counts were carried out as well as glutaraldehyde demand and glularaldehyde microbial kill curves. The glutaraldehyde demand and kill curves were carried out at the as-received $\mathrm{pH}(9.46)$ and an adjusted $\mathrm{pH}$ of 5.8 . An aliquot was also filtered through $0.45-\mu \mathrm{m}$ cellulose acetate and examined under the scanning electron microscope (SEM) in an attempt to identify material that may cause filtration problems.

\section{MATERIAL AND METHODS}

\subsection{INITIAL MICROBIAL COUNTS}

On receipt of the samples, initial microbial counts were performed using Biotrace ${ }^{2}$ dipslides containing nutrient agar with 2,3,5-triphenly tetrazolium chloride, an indicator dye for viable microorganisms. After incubating at roorn temperature for 4-5 days, microbe counts ranging from $10^{4}-10^{5}$ colony forming units per milliliter (CFU/mL) were oblained, not unsimilar to populations found in natural environments (Reference 2 ). Taxonomic classification was not carried out as that effort was beyond the scope of the program.

\subsection{GIUTARALDEHYDE DEMAND}

Glutaraldehyde, a commercially available broad spectrum biocide, is commonly used in industry to control the growth of microorganisms including slime-forming bacteria in process waters (Reference 3). As a reactive chemical, there will be a demand generated by the matrix. Glutaraldehyde demand was established using $500 \mathrm{~mL}$ of sample at both $\mathrm{pH}$ levels, as received $(\mathrm{pH} \mathrm{9.46)}$ and $\mathrm{pH} 5.8$. Glutaraldehyde was introduced to each beaker at $52 \mathrm{ppm}$ and confirmed using Glutatect test kits (Glutatect WT ${ }^{3}$ colorimetric test for 20 to $100 \mathrm{ppm}$ and Glutatect ENV colorimetric test for 2 to $10 \mathrm{ppm}$ glutaraldehyde).

The sample was continually stirred during the course of the experiment using a magnetic mixer. Aliquots werc retrieved initially at 0.25 minutes (the time needed for the introduction of the glutaraldehydc and sampling with the Glutatect kit). After the initial and 0.25 -minute reading. glutaraldehyde testing occurred every 5 minutes after the initial introduction of glutaraldehyde.

\footnotetext{
${ }^{2}$ Biotrace is a registered product of Biotrace International Plc, Bridgend Wales, United Kingdom.

${ }^{3}$ Glutatect WT is a registered trademark of Alden Scientific, Inc., Winthrop, Massachusctts.

${ }^{4}$ Glutatect ENV is a registered trademark of Alden Scientific, Inc., Winthrop, Massachusetts.
} 


\subsection{MICROBIAL KILL}

An inoculum was derived from bacterial growth on the initial dipslides. The newly inoculated dipslide was allowed to establish colonies, which were eluted using Basin 42 sample. The resulting concentration was introduced into $500-\mathrm{mL}$ aliquots of Basin 42 at $\mathrm{pH} 9.46$ and $\mathrm{pH} 5.8$. Glutaraldehyde was introduced at concentrations of $60 \mathrm{ppm}$ (as tested by the Glutatect method). Microbial counts were established using the dipslides described in Section 2.1 at the initial time (before glutaraldehyde introduction), time 0 , time of glutaraldehyde introduction, and 5 minutes thereafter.

\subsection{SCANNING ELECTRON MICROSCOPY}

Two hundred milliters of Basin 42 were filtered through a $0.45-\mu \mathrm{m}$ cellulose acetate filter and scanned using SEM. The SEM analysis also included electron dispersive X-ray spectroscopy (EDS) for elemental analyses.

\section{RESULTS AND DISCUSSION}

\subsection{GLUTARALDEHYDE DEMAND}

Figure 2 shows the results of the glutaraldehyde demand curve described in Section 2.2.

Figure 2. Glutaraldehyde Demand.

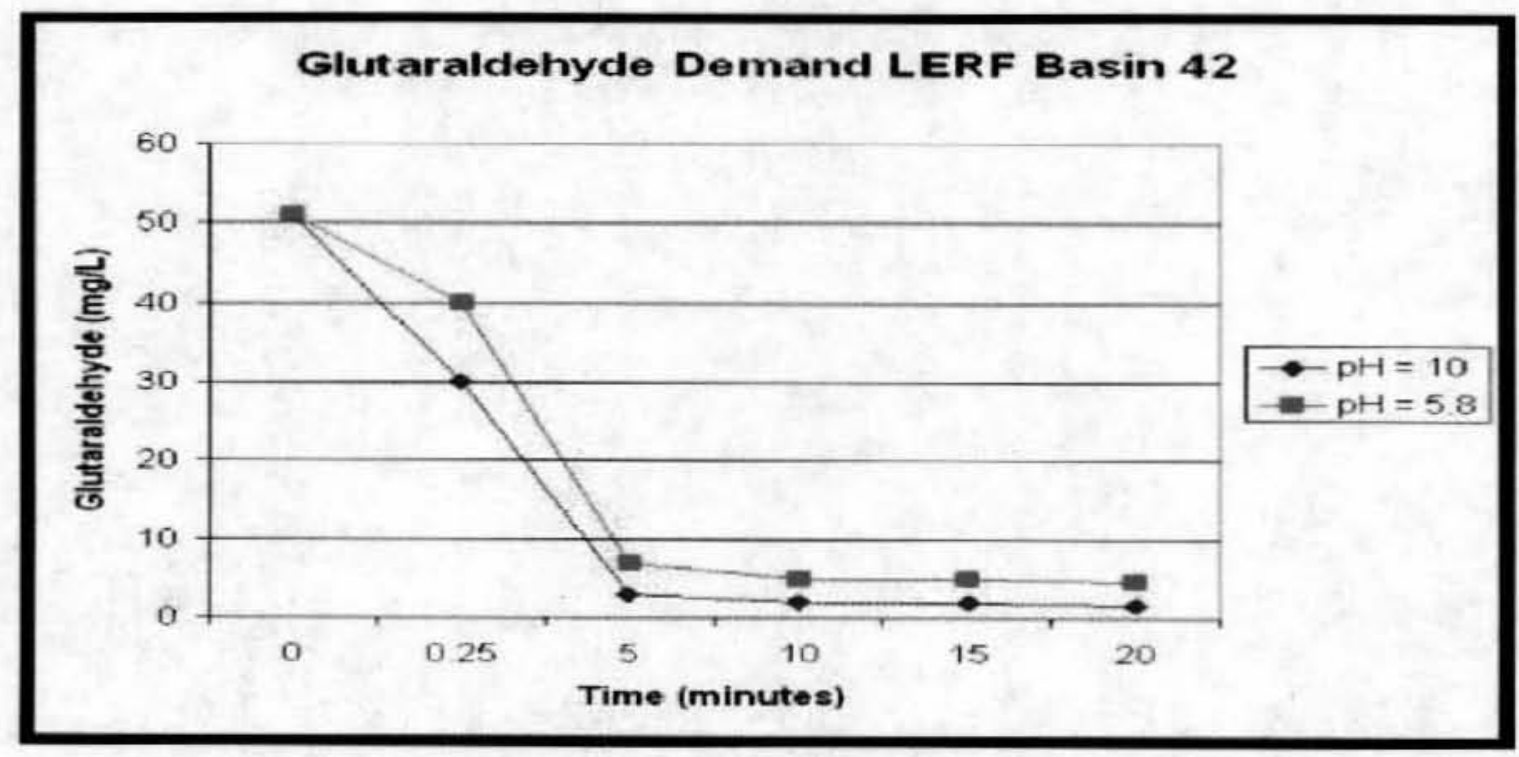


The graph indicates that the glutaraldehyde acts faster at the higher $\mathrm{pH}$. Therefore, if ETF uses glutaraldehyde as a biocide, it would be advisable to do so before $\mathrm{pH}$ adjustment is carried out in the surge tank.

\subsection{MICROBIAL KILL}

Figure 3 shows the efficacy of glutaraldehyde in the Basin 42 matrix at $\mathrm{pH} 9.46$ and ph 5.8 .

Figure 3. Basin 42 Microbial Response to Glutaraldehyde.

\section{Microbial Response to Glutaraldehyde}

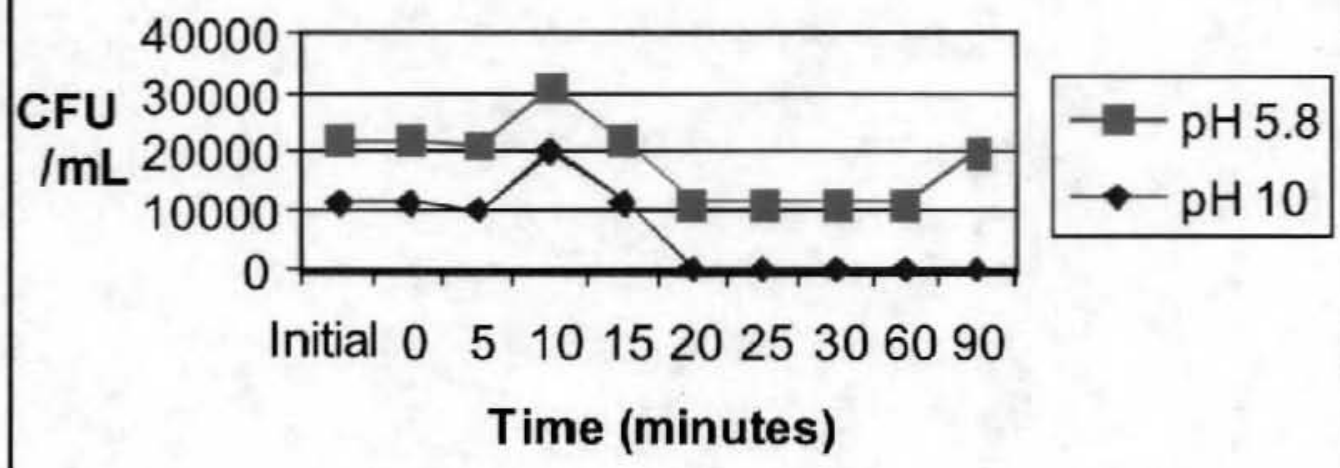

Figure 3 indicates the efficacy of glutaraldehyde as a biocide at the higher $\mathrm{pH}$ range. Again, if the ETF wishes to employ glutaraldehyde as a biocide, the glutaraldehyde will be more efficacious at the as-received $\mathrm{pH}$ versus the adjusted $\mathrm{pH}$.

\subsection{SCANNING ELECTRON MICROSCOPY}

Figure 4 is a SEM photo of material trapped on the influent side of a $0.45-\mu \mathrm{m}$ filter.

The material appearing black is an amorphous mass that was trapped on the surface of the $0.45-\mu \mathrm{m}$ filter. The material within the box was interrogated using EDS without firm results. The area indicated carbon, hydrogen, and oxygen; essentially elements found in hydrocarbons or living organisms. 
Figure 4. SEM of Basin 42 Filter Retentate on 0.45-Micron Filter.

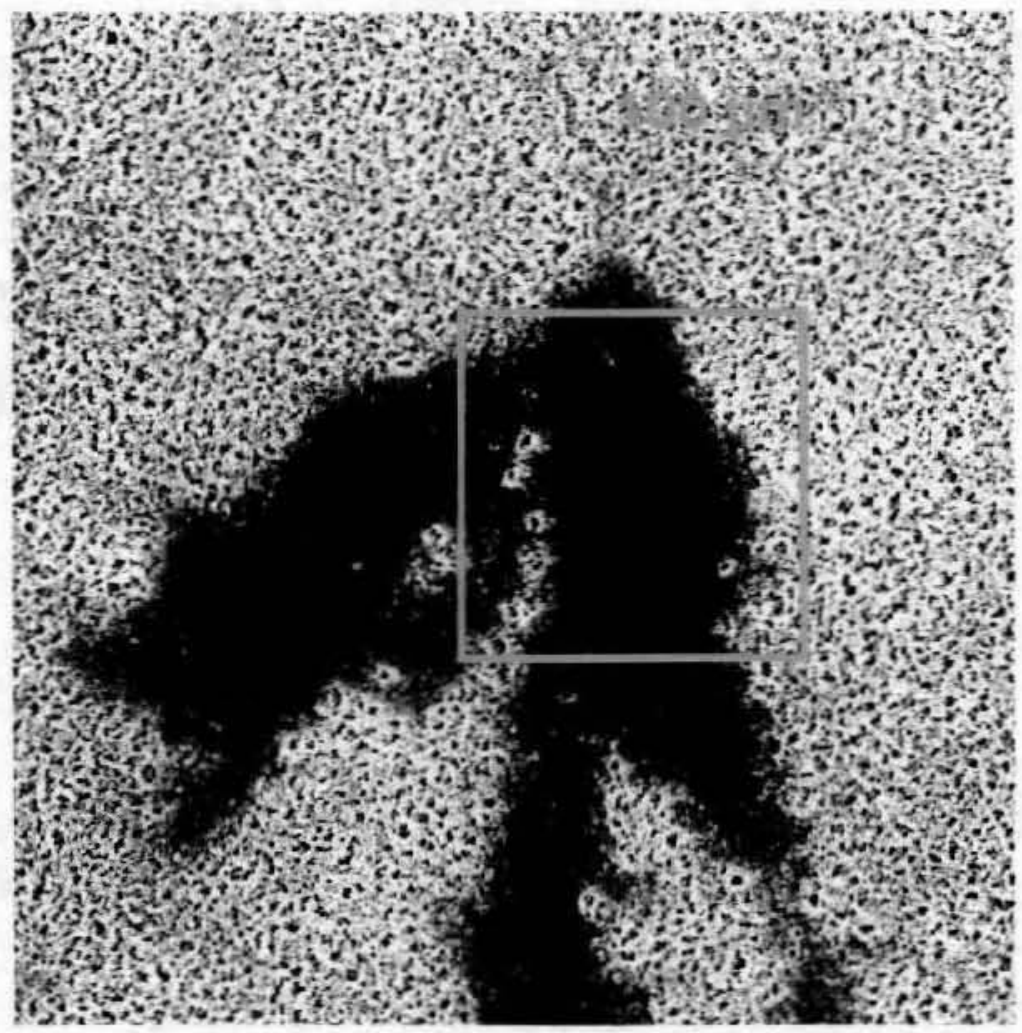

\section{CONCLUSIONS AND RECOMMENDATIONS}

This report indicates the efficacy of glutaraldehyde as a biocide in more alkaline $\mathrm{pH}$ as opposed to the adjusted acidic $\mathrm{pH}$ that ETF requires for their process. At first it was thought that the response of Basin 42 was perhaps due to the particular matrix and colligative properties associated with the matrix. It is unfortunate that the field observations could not be reproduced in the laboratory. This inability did not allow for filtration runs to be performed. This inability to secure a sample that would act the same is probably indicative of the problem being localized in an area of the basin that allows for transfer during pumping but not during sampling. It is recommended that if the gelatinous material occurs during the next campaign, a sample of the gelatinous material be submitted to 222-S Laboratory for analyses to determine the cause.

It has been requested that a filter recommendation be put forth that would enable longer filter runs when confronted with the gelatinous material as in the last Basin 42 campaign. Before launching into a recommendation, it should be stated that gelatinous material encountered in filtration processes is individual in nature; i.e., not all gels are created equal nor react equally in filtration unit operations. Also, any filtration media should have the ability to be retrofitted to existing housing. The following recommendation is based on a priori processes. 
CUNO Incorporaled has reviewed the nature of the gelatinous material inasmuch as photos from the last campaign are able to indicate. After numerous discussions with CUNO technical support and field personnel, the recommendation by the vendor is the CUNO PolyNet. ${ }^{5}$ The PolyNet (Appendix B) is a depth filter designed to filter high viscosity materials in the petroleum industry. Due to the nature of the gelatinous material as shown in the photographs, CUNO . recommended a run time to a delta of $-10 \mathrm{psi}$, then either a backwash or cleaning using hot water $\left(140^{\circ} \mathrm{F}\right)$. (The usual recommended delta $\mathrm{P}$ is $80 \mathrm{psi} @ 68^{\circ} \mathrm{F}$.) The reason for the lower deita $\mathrm{P}$ is to enable cleaning of the filter before the gelatinous material is driven too far into the filter. Also, operating at high delta P's (outside of the manufacturer's recommendation) will degrade the effluent stream by pushing material through the filter.

In addition, CUNO has recommended that the Pall PruSep ${ }^{6}$ fine filters also be replaced with the PolyNet. The replacement would be 36 PolyNet filters with a maximum flow rate of $648 \mathrm{gpm}$. Currently CUNO is preparing a cost proposal for a retrofit filter basket to fit within the existing housing. If agreeable with ETF management, the rough filter housing containing PolyNet filters could be operated in parallel with the fine filter housing containing the ProSep filters. A suggested test configuration is presented in Figure 5 to allow comparative analyses of influent and effluent streams.

Figure 5. Suggested Test Configuration for PolyNet and ProSep Filters.

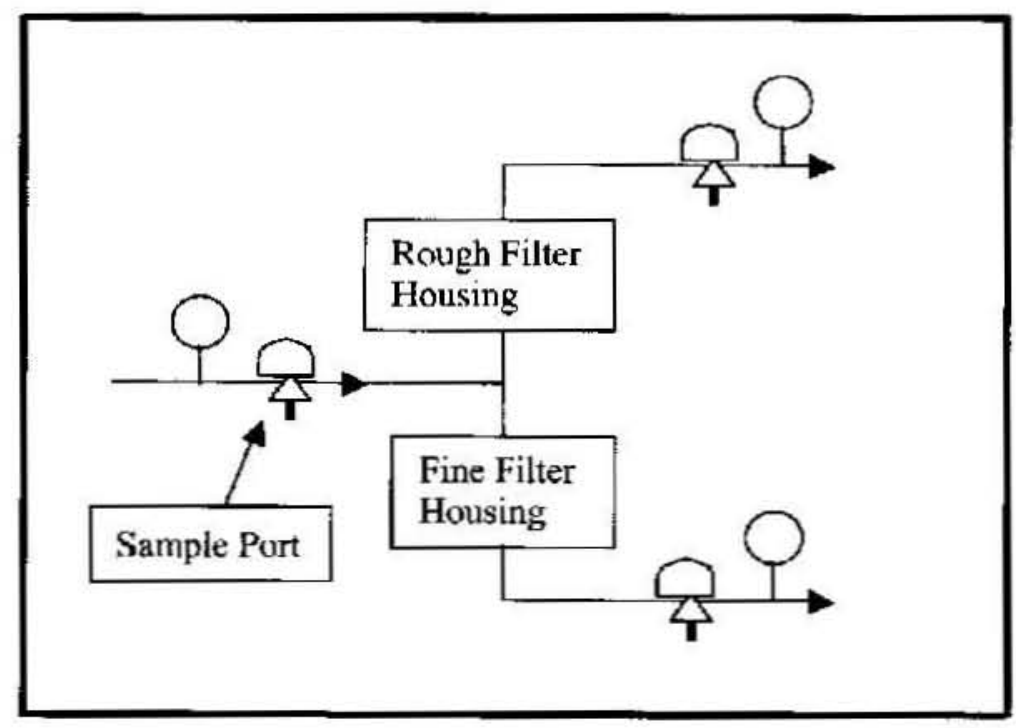

${ }_{6}^{5}$ PolyNet is a registered trademark of CUNO Incorporated, Meriden, Connecticut.

${ }^{6}$ ProSep is a registered trademark of Pall Corporation, East Hills, New York. 
RPP-RPT-22879, Rev. 0

\section{REFERENCES}

1. Duncan, J. B., 2004, RPP-21533, Test Plan for the Biocide Treatment of LERF Basin 42 Feed Using Glutaraldehyde, CH2M HILL Hanford Group, Inc., Richland, Washington.

2. Smith, J. J., and J. C. Priscu, 1993, "Microbial respiration polential in Lake Bonney using a novel tetrazolium-reduction method," Antarctic Journal of the U.S. 28(5): 244-245.

3. Ganzer, G. A., 2001, "Glutaraldehyde: A versatile microbiocide for use in water treatment applications," Analyst, Spring 2001. 
RPP-RPT-22879, Rev. 0

\section{APPENDIX A}

\section{Chemical Analyses}




\section{Chemical Analyses LERF Basin 42}

\begin{tabular}{|c|c|c|c|}
\hline Analyte & Unit & Result & $\begin{array}{c}\text { Detection } \\
\text { Limit } \\
\end{array}$ \\
\hline $\mathrm{pH}$ Direct & $\mathrm{pH}$ & 9.46 & 0.01 \\
\hline TIC by Acid Coulometry & $\mathrm{Hg} / \mathrm{ml}$ & 20.4 & 2.5 \\
\hline TOC by Persulfate/Coulometry & $\mu \mathrm{g} / \mathrm{mL}$ & $<20.0$ & 20 \\
\hline Technetium- 99 by ICP/MS (Acid $A$ ddition) & $\mu \mathrm{g} / \mathrm{mL}$ & 3.49E-06 & $1.50 \mathrm{E}-06$ \\
\hline Tin-126 by ICP/MS (Acid Addition) & $\mu \mathrm{g} / \mathrm{mL}$ & $<1.00 \mathrm{E}-06$ & $1.00 \mathrm{E}-06$ \\
\hline Cesium- 133 by ICP/MS Acid Addition & $\mu \mathrm{g} / \mathrm{mL}$ & $1.39 \mathrm{E}-05$ & $1.00 \mathrm{E}-05$ \\
\hline Cesium- 135 by ICP/MS Acid Addition & $\mu \mathrm{g}^{\prime} \mathrm{mL}$ & $3.10 \mathrm{E}-04$ & $7.50 \mathrm{E}-06$ \\
\hline Cesium- 137 by ICP/MS (Acid Addition) & $\mu \mathrm{g} / \mathrm{mL}$ & $5.60 \mathrm{E}-04$ & $4.50 \mathrm{~F}-06$ \\
\hline Protactinium-231 by ICP/MS & $\mu \mathrm{g} / \mathrm{mL}$ & $<5.00 \mathrm{E}-08$ & $5.00 \mathrm{E}-08$ \\
\hline Thorium-229 by ICP/MS & $\mu \mathrm{g} / \mathrm{mL}$ & $<9.00 \mathrm{E}-08$ & $9.00 \mathrm{E}-08$ \\
\hline Thorium-230 by ICP/MS & $\mu \mathrm{g} / \mathrm{mL}$ & $<7.00 \mathrm{E}-08$ & $7.00 \mathrm{E}-08$ \\
\hline Thorium- 232 by ICP/MS & $\mu \mathrm{g} / \mathrm{mL}$ & 1.79E-05 & $1.20 \mathrm{E}-06$ \\
\hline Uranium-2.33 by ICP/MS Acid Addition & $\mu \mathrm{g} / \mathrm{mL}$ & $<9.00 \mathrm{E}-08$ & $9.00 \mathrm{E}-08$ \\
\hline Uranium-234 by ICP/MS Acid Addition & $\mu \mathrm{g} / \mathrm{mL}$ & $1.19 E-06$ & $3.00 \mathrm{E}-08$ \\
\hline Uranium- 235 by ICP/MS Acid Addition & $\mu \mathrm{g} / \mathrm{mL}$ & $1.56 \mathrm{E}-04$ & $1.10 \mathrm{E}-07$ \\
\hline Uranium 236 by ICP/MS Acid $\Lambda$ ddition & $\mathrm{pg} / \mathrm{mL}$ & $1.98 \mathrm{E}-06$ & $4.00 \mathrm{E}-08$ \\
\hline Lranium- 238 by ICP/MS Acid Addition & $\mu \mathrm{g} / \mathrm{mL}$ & 0.0222 & $5.50 \mathrm{E}-06$ \\
\hline Neptunium-237 by ICP:MS & $\mu \mathrm{g} / \mathrm{mL}$ & $2.02 \mathrm{E}-06$ & $2.70 \mathrm{E}-07$ \\
\hline Plutonium- 239 by ICP/MS & $\mu \mathrm{g} / \mathrm{mL}$ & $2.85 \mathrm{E}-06$ & $6.00 \mathrm{E}-07$ \\
\hline Plutonium-240 by ICP/MS & $\mu \mathrm{g} / \mathrm{mL}$ & $<5.00 \mathrm{E}-08$ & $5.00 \mathrm{E}-08$ \\
\hline Plutonium/Americium-24I by ICP/MS & $\mu \mathrm{g} / \mathrm{mL}$ & $<3.50 \mathrm{E}-07$ & $3.50 \mathrm{E}-07$ \\
\hline Plutonium/Americium 242 ICP/MS (Acid Added) & $\mu \mathrm{g} / \mathrm{mL}$ & $\angle 4.00 \mathrm{E}-08$ & $4.00 \mathrm{E}-08$ \\
\hline Americium $243 /$ Cerium 243 by ICP/MS & $\mu \mathrm{g} / \mathrm{mL}$ & $<5.00 \mathrm{E}-08$ & $5.00 \mathrm{E}-08$ \\
\hline Plutonium $244 /$ Cerium 244 by ICP/MS & $\mu \mathrm{g} / \mathrm{mL}$ & $<9.00 \mathrm{E}-08$ & $9.00 \mathrm{E}-08$ \\
\hline Silver-ICP-Acid Dilution & $\mu \mathrm{g} / \mathrm{mL}$ & $9.26 \mathrm{E}-0.3$ & $5.00 \mathrm{E}-03$ \\
\hline Aluminium-ICP-Acid Dilution & $\mu \mathrm{g} / \mathrm{mL}$ & $<0.0800$ & 0.08 \\
\hline Arsenic-ICP-Acid Dilution & $\mu \mathrm{g} / \mathrm{mL}$ & $<0.0400$ & 0.04 \\
\hline Boron-ICP-Acid Dilution & $\mu \mathrm{g} / \mathrm{mL}$ & 0.0175 & $9.00 \mathrm{E}-03$ \\
\hline Barium-ICP-Acid Dilution & $\mu \mathrm{g} / \mathrm{mL}$ & $<5.00 \mathrm{E}-03$ & $5.00 \mathrm{E}-03$ \\
\hline Beryllium-ICP-Acid Dilution & $\mu \mathrm{g} / \mathrm{mL}$ & $<4.00 \mathrm{~F}-03$ & $4.00 \mathrm{E}-03$ \\
\hline Bismuth-ICP-Acid Dilution & $\mu \mathrm{g}^{\prime} \mathrm{mL}$ & $<0.0600$ & 0.06 \\
\hline Calcium-ICP-Acid Dilution & $\mu \mathrm{g} / \mathrm{mL}$ & 5.92 & 0.02 \\
\hline Cadmium-ICP-Acid Dilution & $\mu \mathrm{g} \mathrm{mL}$ & $\angle 4.00 \mathrm{E}-03$ & $4.00 \mathrm{E}-03$ \\
\hline Cerium-ICP-Acid Dilution & $\mu \mathrm{g} / \mathrm{mL}$ & $<0.0250$ & 0.025 \\
\hline Cobalt-ICP-Acid Dilution & $\mu \mathrm{g} / \mathrm{mL}$ & $<6.00 \mathrm{E}-03$ & $6.00 \mathrm{E}-03$ \\
\hline Chromium-ICP-Acid Dilution & $\mu \mathrm{g} / \mathrm{mL}$ & $<2.50 \mathrm{E}-03$ & $2.50 \mathrm{~F}-03$ \\
\hline Copper-ICP-Acid Dilution & $\mu \mathrm{g} / \mathrm{mL}$ & $7.38 \mathrm{E}-03$ & $2.00 \mathrm{E}-03$ \\
\hline Furopium ICP-Acid Dilution & $\mu \mathrm{g} / \mathrm{mL}$ & $<0.0150$ & 0.015 \\
\hline Iron-ICP-Acid Dilution & $\mu \mathrm{g} / \mathrm{mL}$ & 0.0134 & $2.50 \mathrm{E}-03$ \\
\hline Potassium-ICP-Acid Dilution & $\mu \mathrm{g} / \mathrm{mL}$ & 0.728 & 0.45 \\
\hline Lanthanum-ICP-Acid Dilution & $\mu \mathrm{g} / \mathrm{mL}$ & $<3.50 \mathrm{E}-03$ & $3.50 \mathrm{E}-03$ \\
\hline
\end{tabular}




\begin{tabular}{|c|c|c|c|}
\hline Analyte & Unit & Result & $\begin{array}{c}\text { Detection } \\
\text { Limit }\end{array}$ \\
\hline Lithium-ICP-Acid Dilution & $1 \mathrm{~g} / \mathrm{ml}$ & $<4.00 \mathrm{E}-03$ & $4.00 \mathrm{E}-03$ \\
\hline Magnesium-ICP-Acid Dilution & $\mu \mathrm{g} / \mathrm{mL}$ & 1.35 & 0.025 \\
\hline Manganese-ICP-Acid Dilution & $\mu \mathrm{g} \mathrm{mL}$ & $<5.00 \mathrm{E}-03$ & $5.00 \mathrm{E}-03$ \\
\hline Molybdenum-ICP-Acid Dilution & $\mu \mathrm{g} / \mathrm{mL}$ & $<8.00 \mathrm{E}-03$ & $8.00 \mathrm{E}-03$ \\
\hline Sodium-KCP-Acid Dilution & $\mu \mathrm{g} / \mathrm{mL}$ & 18.1 & 0.04 \\
\hline Neodymium-ICP-Acid Dilution & $\mu \mathrm{g}^{\prime} \mathrm{mL}$ & $<0.0100$ & 0.01 \\
\hline Nickel-ICP-Acid Dilution & $\mu \mathrm{g} / \mathrm{mL}$ & $<0.0200$ & 0.02 \\
\hline Phosphorus-ICP-Acid Dilution & $\mu \mathrm{g} / \mathrm{mL}$ & 0.147 & 0.045 \\
\hline Lead-ICP-Acid Dilution & $\mu \mathrm{g} / \mathrm{mL}$ & $<0.0300$ & 0.03 \\
\hline Sulfur-ICP-Acid Dilution & $\mu \mathrm{g} / \mathrm{mL}$ & 37.4 & 0.03 \\
\hline Antimony-ICP-Acid Dilution & $\mu \mathrm{g} / \mathrm{mL}$ & $<0.0250$ & 0.025 \\
\hline Sclenium-ICP-Acid Dilution & $\mu \mathrm{g} / \mathrm{mL}$ & 0.0488 & 0.04 \\
\hline Silicon-ICP-Acid Dilution & $\mu \mathrm{g} / \mathrm{mL}$ & 4.3 & 0.015 \\
\hline Samarium-ICP-Acid Dilution & $\mu \mathrm{g} / \mathrm{mL}$ & $<0.0150$ & 0.015 \\
\hline Strontium-ICP-Acid Dilution & $\mu g^{\prime} \mathrm{mL}$ & 0.0236 & $4.00 \mathrm{E}-03$ \\
\hline Thorium-ICP-Acid Dilution & $\mu \mathrm{g} / \mathrm{mL}$ & $<0.0250$ & 0.025 \\
\hline Titanium-ICP-Acid Dilution & $\mu \mathrm{g} / \mathrm{mL}$ & $\angle 2.00 \mathrm{E}-03$ & $2.00 \mathrm{E}-03$ \\
\hline Thallium-ICP-Acid Dilution & $\mu \mathrm{g} / \mathrm{mL}$ & $<0.100$ & 0.1 \\
\hline Uranium-ICP-Acid Dilution & $\mu g^{\prime} \mathrm{mL}$ & $<0.0550$ & 0.055 \\
\hline Vanadium-ICP-Acid Dilution & $\mu \mathrm{g} / \mathrm{mL}$ & $9.62 \mathrm{E}-03$ & $5 . \overline{00 \mathrm{E}-03}$ \\
\hline Yttrium -ICP-Acid Dilution & $\mu \mathrm{g} / \mathrm{mL}$ & $<4.00 \mathrm{e}-03$ & $4.00 \mathrm{E}-03$ \\
\hline Zinc-ICP-Acid Dilution & $\mathrm{pg} / \mathrm{mL}$ & $<5.00 \mathrm{e}-03$ & $5.00 \mathrm{E}-03$ \\
\hline Zirconium-ICP-Acid Dilution & $\mu \mathrm{g} / \mathrm{mL}$ & $<5.00 \mathrm{E}-03$ & $5.00 \mathrm{r}-03$ \\
\hline Fluoride-IC-Dionex 500 Coulometry & $\mu \mathrm{g} / \mathrm{mL}$ & $<0.330$ & 0.33 \\
\hline Glycolate-IC-Dionex 500 ORGACD & $\mu \mathrm{g} / \mathrm{mL}$ & $<2.09$ & 2.1 \\
\hline Acetate by IC-Dionex 500 Coulometry & $\mu \mathrm{g} / \mathrm{mL}$ & $<2.53$ & 2.5 \\
\hline Formate by IC-Dionex 500 Coulometry & $\mu \mathrm{g} / \mathrm{mL}$ & $<2.53$ & 2.5 \\
\hline Chloride-IC-Dionex 500 Coulometry & $\mu \mathrm{g} / \mathrm{mL}$ & 4.59 & 0.44 \\
\hline Nitrite-IC-Dionex 500 Coulometry & $\mu \mathrm{g} / \mathrm{mL}$ & $<2.97$ & 3 \\
\hline Sulfate-IC-Dionex 500 Coulometry & $\mu \mathrm{g}^{\prime} \mathrm{mL}$ & 111 & 3.5 \\
\hline Oxalate-IC-Dioncx 500 Coulometry & $\mu \mathrm{g} / \mathrm{mL}$ & $<2.97$ & 3 \\
\hline Bromide-IC-Dionex 500 Coulometry & $\mu \mathrm{g} / \mathrm{mL}$ & $<3.19$ & 3.2 \\
\hline Nitrate-IC-Dionex 500 Coulometry & $\mu \mathrm{g} / \mathrm{mL}$ & 4.74 & 3.3 \\
\hline Phosphate-IC-Dionex 500 Coulometry & $\mu g^{\prime} \mathrm{mL}$ & $<2.97$ & 3 \\
\hline
\end{tabular}

\section{Legend:}

IC ion chromatography

ICP inductively coupled plasma spectroscopy

MS mass spectroscopy

TIC lotal inorganic carbon

TOC total organic carbon 
RPP-RPT-22879, Rcv. 0

\section{APPENDIX B}

\section{CUNO PolyNet Specifications}




\section{PolyNet ${ }^{\circledR}$}

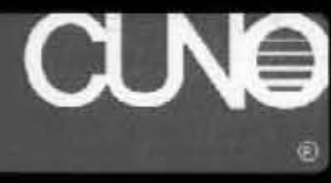

Filter Cartridges

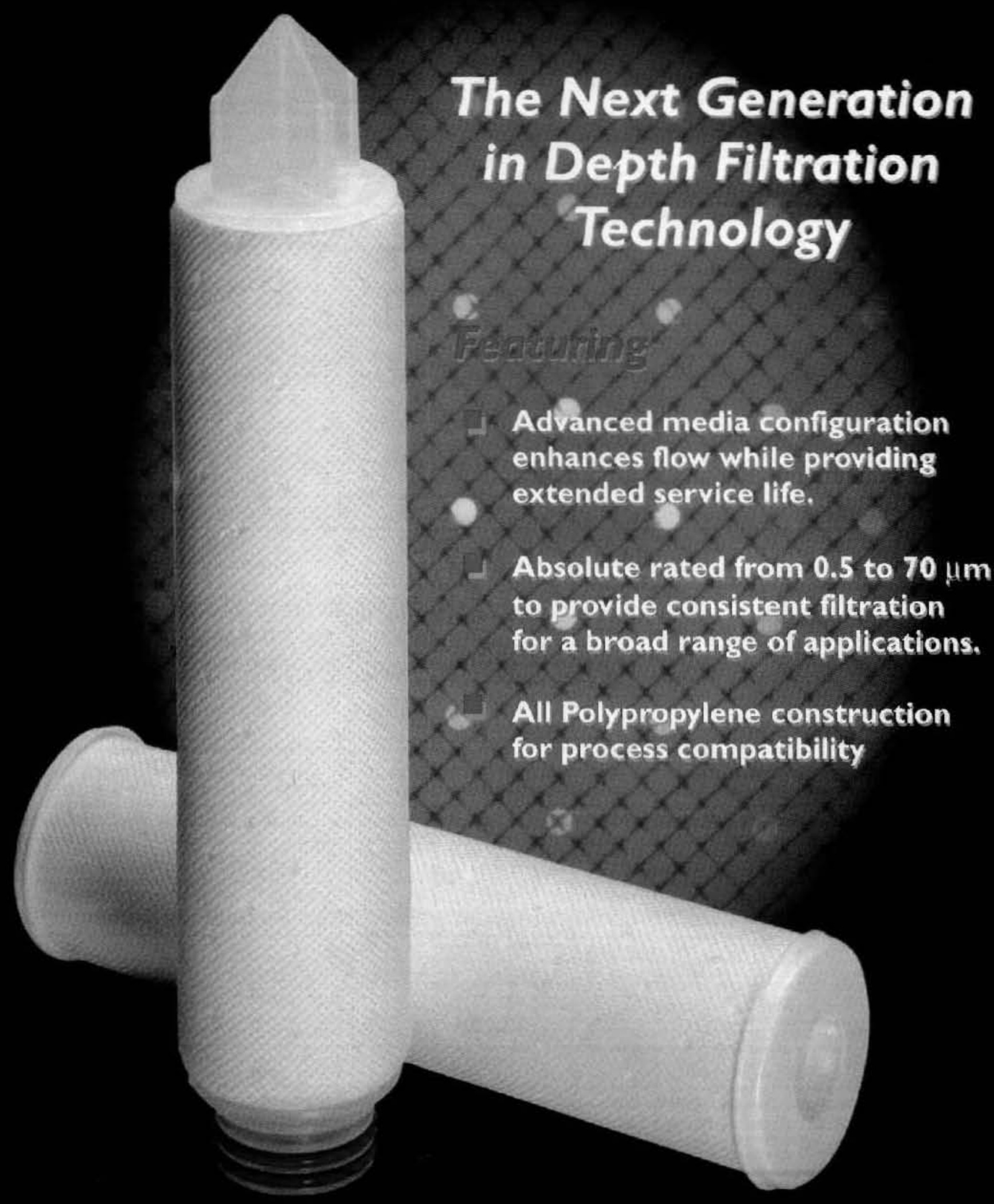




\section{PolyNet ${ }^{\circledR}$ Filter Cartridges The Next Generation In
Depth Filter Technology The Next Generation In
Depth Filter Technology}

PolyNet filter cartridges are CUNO'S latest advance in depth filtration technology. The all polypropylene filter is constructed using a patented ${ }^{*}$ design that utilizes flow enhancing filter media and an innovative flow pattern. The result is an absolute-rated filter with vastly superior on-stream life that provides more cost effective filtration than conventional melt-blown filter technologies.

PolyNet filter cartridges - the new leader in filtration performance!

\section{The PolyNet Advantage}

- Superior Service Life - as much as 4 times greater dirt holding capacity than competitive filters

all polypropylene depth filter cartridges for broad chemical and temperature compatibility

- Ratings from 0.5 - 70 microns to suit a wide range of applications

absolute-Rated Performance for consistent filtration quality

- Exhibits superior particle retention under increasing differential pressure

PolyNet Filter

\section{Construction}

CUNO designed the PolyNet cartridge to provide significantly superior service life while maintaining a consistent filtration efficiency. PolyNet filters achieve this through an innovative cartridge design that allows uniform distribution of fluid flow and contaminant throughout the entire depth of the cartridge. PolyNet filter construction combines a unique polypropylene media with fluid distribution netting to form multiple layers. Critically positioned media flow channels allow greater movement of fluid from layer to layer. Three distinct media sections, made from multiple media/netting layers, are combined to form the filter cartridge.

The outer and middle sections contain multiple layers of interleaved filter media and fluid distribution netting. Within each media layer a portion of the fluid travels through the media while the balance of the fluid is delivered directly to the next distribution layer through the flow channels. The fluid distribution netting provides longitudinal and latitudinal flow paths to evenly distribute fluid flow across the surface of each successive media layer. 


\section{PolyNet ${ }^{\circledR}$ Filter Cartridges The Difference is Performance}

Flow channels appear in the outer and middle sections of the filter matrix, as seen in the cartridge cut-away. The size, number, and location of the flow channels combined with the fluid distribution netting ensure that a uniform amount of contaminant is distributed to each layer within these two sections, while maintaining a consistent flow.

The number of media flow channels decrease from the outer to middle sections to ensure even contaminant loading throughout the entire filter matrix. Extensive laboratory testing has demonstrated that Cuno has developed the optimal filter cartridge design.

The inner section, supported by a rigid polypropylene core and equal to approximately one third of the filter's depth, contains no flow channels and is the final qualifying section ensuring absolute rated performance.

The even distribution of contaminated fluid throughout the depth of the cartridge is the key to PolyNet filters exceptionally long service life, low pressure drop, and increased cost effectiveness.

\section{The Result}

\section{Superior Filter Service Life}

Extensive testing has demonstrated that competitive filters of equivalent removal ratings subjected to the same contaminant load plug more quickly than PolyNet filters. The result is significantly shorter service life, and unpredictable filtration efficiencies. PolyNet filters provide a service life improvement of up to 3 times greater than competitive products! (Graph 1)

\section{Lower Pressure Drop}

The unique design and construction of the PolyNet cartridge allow for significantly lower pressure drops compared to equivalently rated melt-blown depth filters. Based on published

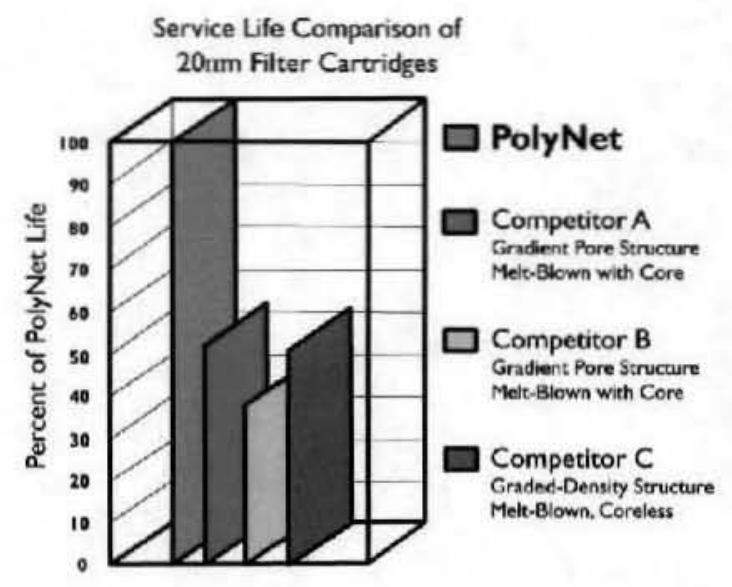
data, a PolyNet filter system with a given flow would use up to $75 \%$ fewer cartridges than Osmonics Selex, $68 \%$ fewer than Pall Profile, and $42 \%$ fewer than Filterite Nexis! To underscore the PolyNet filter cost benefit, use the example in Table 1 as a guideline.

\begin{tabular}{|c|c|c|c|c|}
\hline & PolyNet Filters & Pall Profile ${ }^{x}$ & Filterite Nexis" & Osmonics Selex* \\
\hline Flow (gpm) $/ 10^{-}$cartridge 1 psid & 3.1 & 1.0 & 1.8 & 0.8 \\
\hline Number of filters for a $110 \mathrm{gpm}$ flow rate & $12 / 30^{\prime \prime}$ cartridges & $37 / 30^{\circ}$ cartridges & $21 / 30^{\prime \prime}$ cartridges & 43/30" cartridges \\
\hline
\end{tabular}

For the same initial cartridge differential pressure, a $110 \mathrm{gpm}$ system using PolyNet filters require significantly fewer cartridges. This results in lower capital investment for the filter housing and fewer cartridges to purchase. 


\section{PolyNet ${ }^{\oplus}$ Filter Cartridges}

\section{The Confidence of Consistency}

PolyNet filters utilize advanced design and construction to achieve a level of filtration consistency unattainable by competitive filters. Combined with an exceptionally long service life, the PolyNet filter's consistent performance, as illustrated by comparative Beta-Ratio vs. Differential Pressure (Graph 2), provides predictable results throughout the usable filter life. Filters A, B, and C show a degradation in the Beta-Ratio as psid increases. These filters exhibit a pattern of either unloading previously held particles or a loss of filtration efficiency. The result of this inconsistent performance is a reduction in finished product quality, product yield, and an increase in total filtration cost!

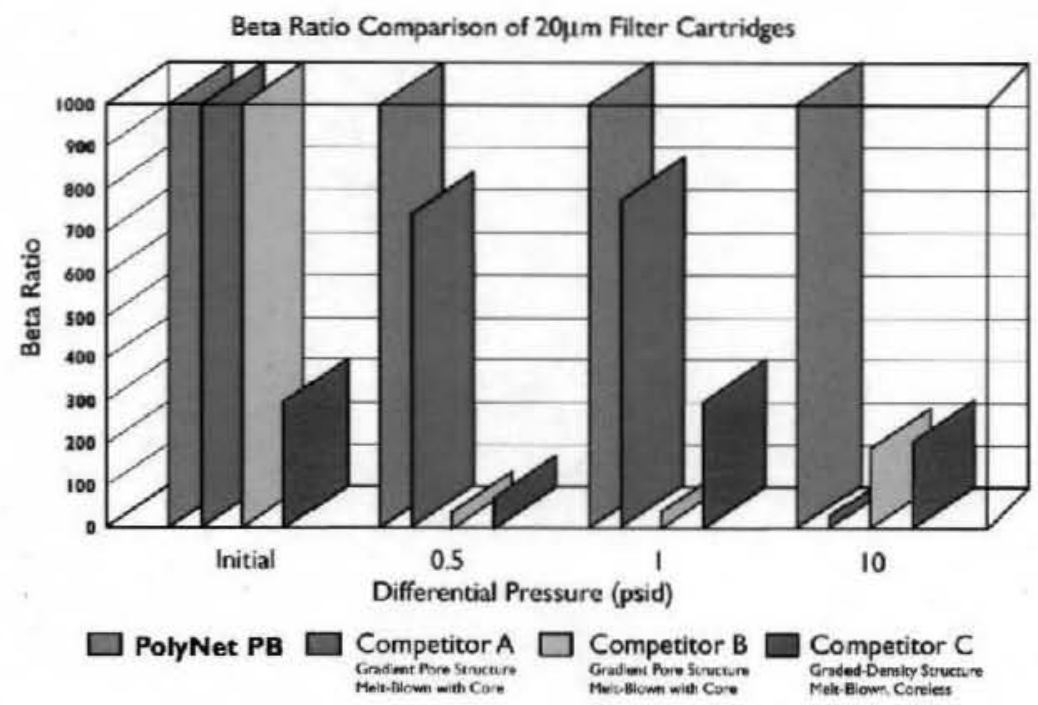

Graph 2. - Beta Ratios demonstrate the PolyNet filter's ability to perform consistently throughout its life

\section{Absolute PolyNet}

Consistent filtration performance, time after time, from start to finish - the goal of every filter user, the solution provided by PolyNet filters! Absolute removal ratings for PolyNet filters are determined using a filter performance test developed by CUNO to comply with the general procedures outlined in ASTM STP 975. CUNO defines absolute rating as the particle size $(\mathrm{x})$ providing an initial Beta Ratio $\left(\mathrm{B}_{\mathrm{x}}\right)=$ 1000. At this Beta Ratio, the removal efficiency is equal to $99.9 \%$. PolyNet filter ratings are specified in Table 2.

\section{Your Benefit - Total Filtration Cost Reduction}

The PolyNet filter's performance and superior life advantage allow direct cost savings by reducing the number of filters used. In addition, the resulting reduction in filter change-out frequency decreases direct labor and filter disposal costs. PolyNet filter cartridges providing performance and value!

Table 2. - PolyNet Filter Ratings

\begin{tabular}{|c|c|}
\hline Grade Designation & $\begin{array}{c}\text { Absolute Rating } \\
\text { (Microns) }\end{array}$ \\
\hline T005 & $0.5^{*}$ \\
\hline T010 & 1 \\
\hline T020 & 2 \\
\hline T030 & 3 \\
\hline T050 & 5 \\
\hline T100 & 10 \\
\hline T200 & 20 \\
\hline T300 & 30 \\
\hline T400 & 40 \\
\hline T500 & 50 \\
\hline T700 & 70 \\
\hline
\end{tabular}




\section{PolyNet ${ }^{\circledR}$ Filter Cartridges PolyNet Filter Applications}

PolyNet's unique patented construction provides benefits to customers in a wide range of end-use filtration applications. High quality filtration along with total filtration cost reductions are very attractive benefits to customers in diverse industries.

Chemical and Hydrocarbon Processing Applications - Cost reduction is the most critical issue in the production of high quality chemicals, petrochemicals, and in hydrocarbon processing. Using PolyNet filters in demanding applications that require absolute-rated performance provides long service life, the consistency demanded to attain quality standards, and a total Filtration Cost reduction! Applications include:

= Acids, bleach (sodium hypochlorite)

a Polyethylene and polypropylene manufacture

amine sweetening and waterflood

Food \& Beverage Applications - Increased consumer emphasis on product quality, as well as increased government regulation, are driving today's food \& beverage industry to ever-finer levels of filtration. PolyNet filter cartridges meet this challenge throughout their entire service life. Typical applications include:

- Bottled water particulate and turbidity reduction

- Reverse osmosis membrane and spray nozzle protection

- Diatomaceous earth or carbon fine trap

= Beverage blending, rinsing, or wash water

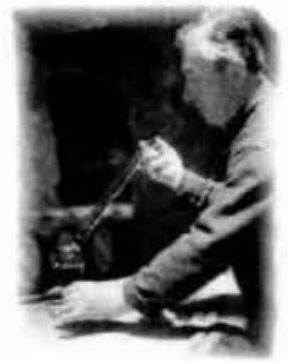

Fine Chemical and Electronics Applications - PolyNet filters with their unique filter matrix are ideally suited for electronics applications where heavy contaminant loading is present and efficient long lasting filtration is required. The combination of all-polypropylene construction and the unique media provide the perfect filtration device for use in wafer manufacturing and semiconductor device fabrication. Applications include:

a Pre-RO filtration of high silt density index incoming water

- Copper sulfate plating bath filtration in printed circuit board construction

- Color screen filtration for CRT production

Coating Applications - PolyNet filter cartridges are well suited for the filtration of high solid coatings where they provide superior life while selectively removing the large undesired particles from the coating and allowing the smaller desired particles to pass. PolyNet applications include:

a Film \& paper coatings

= Photographic film

- Lens coatings \& magnetic media

- Can coatings, high quality paints, \& ink

Industrial Applications - PolyNet filter cartridges are ideal for higher dirt loads because of the unique flow characteristics and long service life that provide reduced overall filtration costs. PolyNet cartridges are used in a broad range of general industrial applications that include:

- Machine tool lubrication, chemicals, detergents, and waste water

- Textiles, plating baths

- Pulp \& paper

- Process water \& ground water remediation 


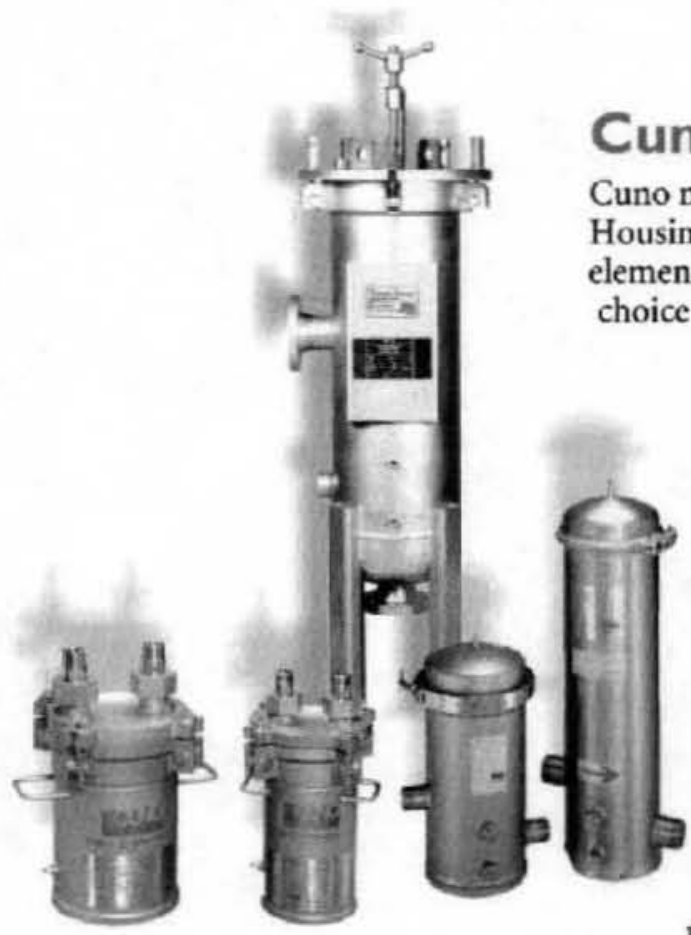

\section{Cuno Filter Housings}

Cuno manufactures a wide range of filter housings. Housings that accommodate from a single filter element, to many hundreds, available in a broad choice of materials, and a flexibility of design ensure

that Cuno has a filter housing to suit your needs.

ES Series Filter Housing - The ES Series filter housing is a durable high volume filter housing constructed from $316 \mathrm{~L}$ stainless or carbon steel. With a cartridge capacity from 12 to 480 equivalent lengths, the ES filter can accommodate a wide range of flow requirements. For more information, ask your local Cuno distributor for brochure LITCHSES1.

CTG-Klean ${ }^{*}$ Filter Housing - A unique design provides a totally enclosed system using separate pressure vessel and filter pack to isolate process fluid from the housing. This system virtually eliminates the costs involved with filter change-out while protecting the environment and operator from exposure to the process fluid. For more information, ask your local Cuno distributor for brochure LITCCK001.

DC \& SD Filter Housings - DC and SD filter housings offer a cost effective alternative for low volume filtration. Constructed from reliable 304L stainless steel (Model DC) or 316L stainless steel (Model SD), systems are available for a wide range of flow rates and applications. For more information, ask for literature LITHSDC1 and LITHSSD1.

\section{PolyNet ${ }^{8}$ Specifications}

\begin{tabular}{|c|c|}
\hline Filter Media, Netting, Core, End Connector & Polypropylene \\
\hline Gaskets \& O-ring Options (see ordering guide) & $\begin{array}{l}\text { Silicone, Fluorocarbon, EPR, Nitrile, Teflon Encapsulated Viton, and } \\
\text { Polyethylene }\end{array}$ \\
\hline \multicolumn{2}{|l|}{ Operating Conditions } \\
\hline Maximum Operating Temperature & $180^{\circ} \mathrm{F}\left(82^{\circ} \mathrm{C}\right)$ \\
\hline \multirow{3}{*}{ Maximum Differential Pressure } & 50 psid at $86^{\circ} \mathrm{F}$ ( 3.4 bar at $\left.30^{\circ} \mathrm{C}\right)$ \\
\hline & 30 psid at $131^{\circ} \mathrm{F}\left(2.0\right.$ bar at $\left.55^{\circ} \mathrm{C}\right)$ \\
\hline & 15 psid at $180^{\circ} \mathrm{F}$ ( 1.0 bar at $82^{\circ} \mathrm{C}$ ) \\
\hline Recommended Change-Out Differential Pressure & 35 psid at $86^{\circ} \mathrm{F}\left(2.4\right.$ bar at $\left.30^{\circ} \mathrm{C}\right)$ \\
\hline \multicolumn{2}{|l|}{ Cartridge Dimensions } \\
\hline Inside Diameter & $13 / 32^{\prime \prime}$ nominal \\
\hline Outside Diameter & $21 / 2 "$ nominal \\
\hline Length & $5,91 / 4,10,191 / 2,20,291 / 4,30,39$, and 40 inches \\
\hline
\end{tabular}

- All materials are FDA compliant per 21 CFR, Teflon and Viton are registered trademarks of E. I. du Pont de Nemours and Company. 


\section{Flow Rates}

Flow vs. differential pressure in water is depicted for each PolyNet filter grade in the graph below. Detailed information for calculating flows for fluids with other viscosities is located in the following table. Use the formula in conjunction with the values from columns 3 or 4 in the table. The specific pressure drop values may be effectively used when three of the four variables (viscosity, flow, differential pressure, and cartridge grade) are set.

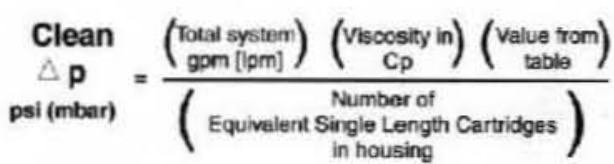

\begin{tabular}{|c|c|c|c|}
\hline \multicolumn{4}{|c|}{ PolyNet Flow Rates } \\
\hline \multirow{2}{*}{ Grade } & \multirow{2}{*}{$\begin{array}{l}\text { Absolute } \\
\text { Rating } \\
\text { ( } \mu \mathrm{m})\end{array}$} & \multicolumn{2}{|c|}{ Specific Pressure Drop per $10^{n}$ Cartridge* } \\
\hline & & $\mathrm{psid} / \mathrm{gpm} / \mathrm{cps}$ & mbar/lpm/cps \\
\hline T005 & 0.5 & 4.5 & 81.9 \\
\hline T010 & 1 & 2.5 & 45.5 \\
\hline T020 & 2 & 0.87 & 15.9 \\
\hline T030 & 3 & 0.44 & 8.0 \\
\hline T050 & 5 & 0.32 & 5.9 \\
\hline T100 & 10 & 0.14 & 2.5 \\
\hline $\mathrm{T} 200$ & 20 & 0.065 & 1.2 \\
\hline T360 & 30 & 0.05 & 0.91 \\
\hline $\mathrm{T} 400$ & 40 & 0.042 & 0.76 \\
\hline Tse0 & 50 & 0.029 & 0.52 \\
\hline 1700 & 70 & 0.025 & 0.45 \\
\hline \multicolumn{4}{|c|}{$\begin{array}{l}\text { - Specific aqueous pressure drop at ambient temperature for a } \\
\text { single length equivalent }\left(10^{\circ}\right) \text { cartridge. For multiple cartridge } \\
\text { lengths, divide the total flow by the number of equivalent lengths. } \\
\text { For liquids other than water, multiply the specific pressure drop } \\
\text { value provided in the table by the viscosity in centipoise. }\end{array}$} \\
\hline
\end{tabular}

\section{Chemical Compatibility}

The $100 \%$ polypropylene construction provides excellent chemical compatibility in many demanding process fluid applications. Compatibility is influenced by process operating conditions: in critical applications, cartridges should be tested under actual conditions to ensure correct selection.

\section{Scientific Application Support Services (SASS)}

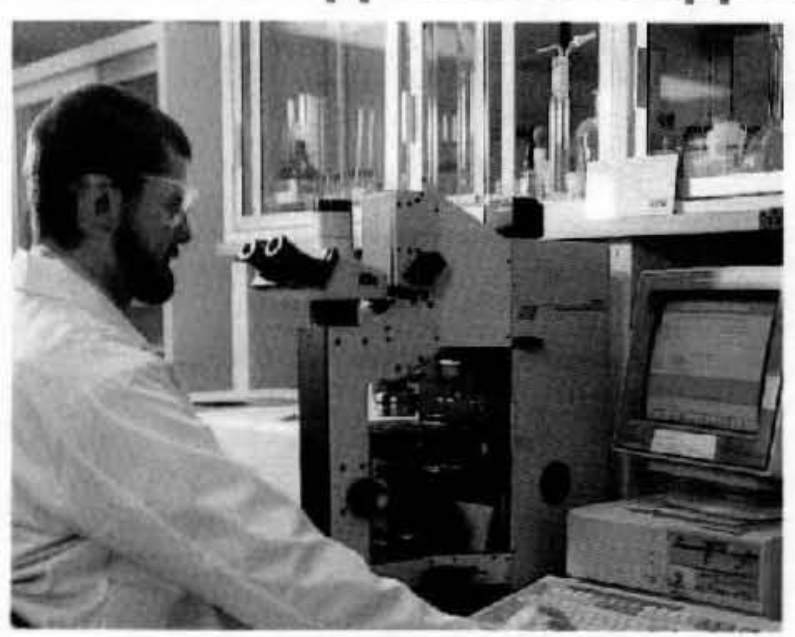

Dedicated technical support teams comprised of Cuno scientists and engineers are available to provide application specific recommendations for the most effective and economical filtration system. In addition to comprehensive testing and analysis conducted at Cuno's advanced laboratories, the SASS staff frequently performs on-site testing at customer's facilities. Contact you Cuno representative for additional information. 


\section{PolyNet Ordering Guide}

\begin{tabular}{|c|c|c|c|c|c|c|c|}
\hline Cartridge & Length. & & ade & Packagng & Dotion 2 , & End Modification free Iluntration & Grabeto-rine Material \\
\hline Type & (inches) & Code & Rating & Option & & betow) & \\
\hline $\mathbf{T}=$ PolyNet & $06^{t}-5$ & T005 & 0.5 & S-Standard & For Fnd Modification & B 2260 Ring with Spcar & For End Modification \\
\hline & $09-9 y^{2}$ & To10 & 1 & & D.N.P. \& R & C. -222 O-Ring with Spear & B. C, D, E, M, \&,Y \\
\hline & $10-10$ & T020 & 2 & & 0 -None & D. DOE with Polypropviene & A-Silicone \\
\hline & $19-191 / 2 *$ & T030 & 3 & & For End Modification & End Caps & B - Fluorocarbon \\
\hline & $20-20$ & T050 & 5 & & B, C, F, M \& Y & $\mathrm{F}-222$ O-Ring with Flat Cap & C. EPR \\
\hline & $29-29 \frac{1 / 4}{}$, & $\mathrm{T} 100$ & 10 & & 1-Polysulfone & M - 222 O-Ring with Flat Cap** & D-Nitrile \\
\hline & $30-30$ & T200 & 20 & & 2-Stainless Steel & $\mathrm{N}$ - Unmodified DOE & K - Teflon Encapsulated \\
\hline & $39-39^{*}$ & T300 & 30 & & 0 -None & P-Polypropylene Core Extender & Viton O-Ring \\
\hline & $40-40$ & T400 & 40 & & & Q-SOE, End Cap without Spring & For End Modification \\
\hline & & T500 & 50 & & & R - SOE, End Cap with Spring & $\mathrm{N}, \mathrm{P}, \mathrm{Q}, \boldsymbol{\&} \mathrm{R}$ \\
\hline & & 1700 & 70 & & & $\mathrm{Y}$-Single $\mathrm{O} \cdot \mathrm{ring}\left(40^{\prime \prime}\right.$ length only) & G-Polyethylene \\
\hline
\end{tabular}

'Requires N end modification for use in CT101 (PN 44860) only 'Applies to D, N, and P end modifications only * for use with 1 ZMP housing
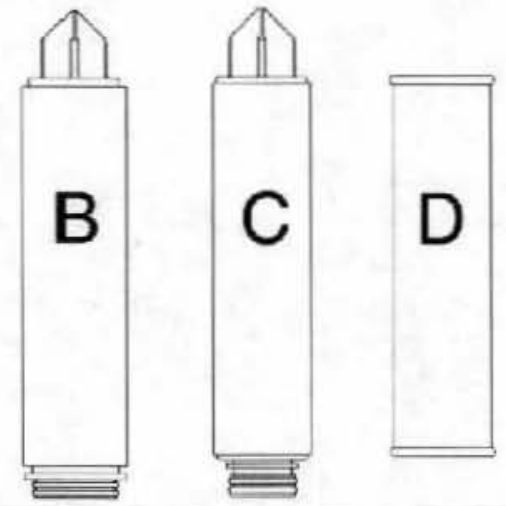

WARRANTY
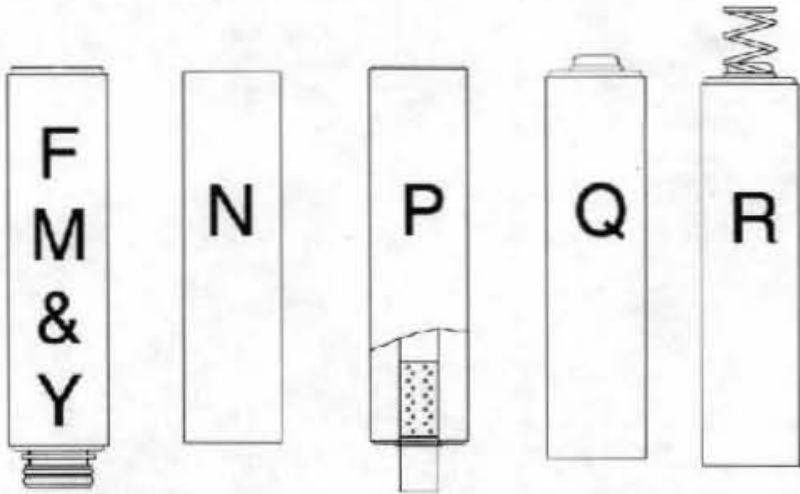

Your Local Cuno Distributor:

Seller warrants its eyuipment against defects in workmanihip and material for a period of 12 months from dat: of thipment from the factory under normal use and service and etherwise when such equipment is used in accordance with instructions fumislied by Seller and for purposes disclosed in writing at the time of purchasc, if any. Any uaauthorized alteration or nedificatien of the equipment by Buyer will void this warranty. Seller' liability under this warranty shall be linited to the ieplacerient ar nepair, Y.O.B. point af manufacture, of any defective equipment or part which, having been returaed to the factory, transportation charges prepaid, has hern inspected and determined by the Seller to be defective. THIS WARRANTY IS IN LIEU OF ANY OTHER WARRANTY, EITHER EXPRESSED OR IMPLIED, AS TO DESCEUPTION, QUALTTY, MFRCHANTABILTTY, FTTNESS FOR ANY PARTICULAR PURPOSE OR USE, OR ANY OTHER MATTEE Under ne circumstances shall Seller be liable to Buyer or any third party for any bass of profitu or other direct of indired msts, expenses, lesses or consequential damages arising out of er as a rault of any defects in or failure of is producti er any pur ar parts thereof or arising ovt of or asa result of parts ex compunents insorpurated in Seller'sequipment har nor aupplied by the Seller

\section{Service Worldwide}

Visit us at www.cuno.com for more information about CUNO Products or the location of your local sales office

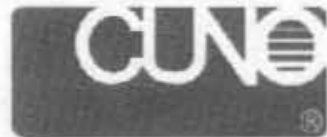

Fluid Purification
CUNO Fitration Asia Pte Ltd 18 Tuas Link 1 ( $3^{n}$ Floor)

Singapore 638599

Cuno Filtration Shanghai Co, Ltd No. 2 Xin Miao San Rd,

Xin Miao Town,

Song Jlang District Shanghai. China. 201612
CUNO Pacific Ply Ltd

140 Sunmyhott Road

Blacktown, NSW 2148

Australia

CUNO K.K.

Hodogaya Station

Building 6F

1-7 Iwai-cho, Hodogaya-ku Yokohama 240 Japan
CUNO Latina Ltda Rua Amt Do Brasil 251

18120 Mairinque-Sp Brazil

CunO Ltd

21 Woking Business Park Albert Drive

Wolking, Surrey GU215JY United Kingdom
Cuno Incorporated

400 Research Parkway Meriden, CT 06450, U.S.A.

Tele: (800) 243-6894

(203) 237-5541

Fax: (203) 238-8977 